WIELKIE TEMATY KULTURY W LITERATURACH SŁOWIAŃSKICH

Slavica Wratislaviensia CLXVIII • Wrocław 2019•AUWr No 3875

DOI: 10.19195/0137-1150.168.20

Data przesłania artykułu: 18.09.2017

Data akceptacji artykułu: 30.12.2017

KLAUDIA KOCZUR-LEJK

Uniwersytet Szczeciński, Polska

\title{
Traktaty o czterech ostatecznych rzeczach człowieka w literaturze czeskiej XVI i XVII wieku. Zarys problematyki
}

Konieczność śmierci — nieodwołalnie czekające człowieka zniszczenie bytu fizycznego i więzi ze światem — od zawsze rodziła lęk, osłabiając poczucie sensu istnienia oraz motywację aktywności życiowej. Bojaźń dopełniała niepewność losów duszy ludzkiej w zaświatach.

Wątki eschatologiczne dogłębnie rozpatrywali filozofowie antyczni, próbując pomniejszyć tragizm śmierci i jej groźną moc. W swych wywodach wskazywali, jak uczynić ze śmierci swoją przyjaciółkę, jak spojrzeć jej w twarz z poczuciem determinacji, dumy lub lekceważenia, aby ocalić godność. Najsilniejszy impuls wiary w triumf życia nowożytna kultura europejska czerpała jednak z religii chrześcijańskiej. Chrześcijaństwo w swojej formule ewangelicznej nie odwołuje się do fikcji pocieszycielskich sformułowanych w filozofii antycznej, potwierdza natomiast egzystencjalne doświadczenie lęku1 ${ }^{1}$.

Jak odnotowała Alina Nowicka-Jeżowa:

W świetle wiary przygotowanie do śmierci, a właściwie sztuka umierania — nie tylko fizycznego, w ostatniej godzinie, ale i duchowego „dla świata i grzechu” — staje się dla chrześcijanina sprawą najważniejszą. Śmierć przedstawia się bowiem jako najdonioślejszy moment egzystencji ziemskiej: sumuje dorobek życia i wprowadza w wieczność2 .

Nauka o życiu jako drodze do śmierci oraz o niej samej jako o kulminacji i przełomie egzystencji tłumaczy rozkwit chrześcijańskiej sztuki umierania.

${ }^{1}$ Por. A. Nowicka-Jeżowa, Pieśni czasu śmierci. Studium z historii duchowości XVI-XVII wieku, Lublin 1992, s. 6-9.

2 Ibidem, s. 10. 
O rozwoju ars moriendi świadczy niezliczona ilość piętnasto-, szesnasto- i siedemnastowiecznych podręczników mających na celu przygotowanie człowieka do dobrej śmierci ${ }^{3}$. Zaangażowanie to było znakiem wiary $w$ to, że człowiek zmierza do źródła swego istnienia, do Boga, a także wyrazem przekonania o odpowiedzialności za własne życie i możliwości wpływania na nie.

Utworami związanymi ze „sztuką umierania” były traktaty o czterech rzeczach ostatecznych (quattuor hominum novissima), czyli śmierci, sądzie, piekle i niebie, które uświadamiały odbiorcom konsekwencje obranego stylu życia doczesnego. Pamięć o „czworakiej wieczności” miała być dla chrześcijanina najlepszą zachętą do pokuty i poprawy. Na długą serię tematyczną składają się pisane początkowo po łacinie, wkrótce jednak także w językach narodowych teksty pojawiające się nieprzerwanie i z dużą częstotliwością od XIV po XVIII wiek ${ }^{4}$.

Jacek Sokolski zwraca uwagę, że

kolejne realizacje tematu nie grzeszyły oryginalnością, ale też nie ona była celem najczęściej stawianym sobie przez autorów. Sam temat, mocno wpisany w oficjalną naukę Kościoła, nie skłaniał raczej do szukania ujęć nowatorskich, wręcz przeciwnie: wtórność i dobitnie podkreślana przy każdej okazji zależność od prac poprzedników stanowiły, jak się wydaje, swoistą gwarancję wyznaniowej prawowierności. Dlatego systematyczna lektura tych tekstów bywa zajęciem dość nużącym. Bez przerwy powtarzają się w nich te same myśli, formuły i obrazy, a co więcej pojawiają się w tych samych miejscach, realizując utrwalony w tradycji schemat wypowiedzi. Powtarzalność ta była jednak zabiegiem celowym i przemyślanym, wynikającym z przyznania szczególnej roli pamięci, którą dzieła de quattuor novissimis [...] miały kształtować i utrwalać dla zbudowania wiernych. Schemat czterech rzeczy ostatecznych był prostym i czytelnym systemem mnemotechnicznym, w którego ramach każdy element, co wynikało z przyjęcia reguł tzw. sztuki pamięci, powinien znajdować się w ściśle określonym miejscu 5 .

W czwórkowym planie symbolicznym podział ten dobrze stosował się do dzieł traktujących o kresie ziemskiej egzystencji człowieka, gdyż tak jak trójka kojarzona była z pierwiastkiem boskim, czwórkę wiązano z tym, co ziemskie czy

${ }^{3} \mathrm{Na}$ ziemiach czeskich książki o dobrym umieraniu zdobyły popularność w drugiej połowie XVI i pierwszej połowie XVII wieku. Na początku pojawiły się przekłady dzieł europejskich znawców tematu, zarówno z protestanckiego, jak i katolickiego obozu, które spopularyzowały wiedzę na temat przygotowania człowieka do śmierci i wywarły wpływ na oryginalną twórczość czeską. Od drugiej połowy XVI wieku zaczęły pojawiać się w Czechach książki o „,dobrej śmierci” rodzimych autorów, którzy należeli do różnych ugrupowań religijnych, byli wśród nich katolicy, kalikstyni oraz członkowie jednoty braterskiej. Więcej na ten temat zob. P. Král, , Knižka o smrti” Mikuláše Krupěhorského př́prava ke smrti v českém prostředi na přelomu 16. a 17. století, [w:] K výzkumu zámeckých, měštanských a cirkevnich knihoven, „Vita Morsque et Librorum Historia (Opera Romanica)” 2006, nr 9, s. 141-153; P. Král, Knihy o dobrém umírání v českém prostředí ve druhé polovině 16. a první půli 17. století, [w:] Církev a smrt. Institucionalizace smrti v ranem novověku, red. M. Holý, J. Mikulec, Praha 2007, s. 7-22.

${ }^{4}$ Tematyka czterech rzeczy ostatecznych była również podejmowana w pieśniach. Zob. J. Vašica, Písně o čtyřech poslednich věcech člověka, Praha 1944.

${ }^{5}$ J. Sokolski, Wprowadzenie do lektury, [w:] K. Bolesławiusz, Przeraźliwe echo trąby ostatecznej, Warszawa 2004, s. 6. 
materialne: cztery strony świata, cztery pory roku, cztery żywioły, cztery temperamenty, a konsekwentnie cztery końce ziemskiego pielgrzymowania człowieka ${ }^{6}$.

Pierwszym czeskim drukiem poświęconym w całości systematycznemu wykładowi nauki o czterech rzeczach ostatecznych było dzieło wydane przez Mikuláša Konáča w 1521 roku: Srdečné knižky o čtyřech posledních budúcích věcech, totiž o smrti, soudu, peklu a o radosti nebeské velmi príkladné. Též knižky, kteréž slovú Zrcadlko sedmi dnů hříñé duše, každému člověku potřebné a užitečné Traktat jest przekładem utworu łacińskiego z końca XIV wieku Cordiale quattuor novissimorum, przypisywanego Gerardusovi de Vliederhovenowi. Tekst ten był bardzo popularny w piętnastowiecznej Europie, o czym świadczy ponad 200 łacińskich rękopisów z XV wieku, 46 łacińskich druków i 27 edycji utworu w językach narodowych w latach $1471-1500^{8}$.

Zamieszczony przez Konáča dodatek do dzieła, zatytułowany Zrcadlko sedmi dnů hřišné duše, stanowi według Vladislava Dokoupila tłumaczenie łacińskiego Speculum hebdomale Jacoba de Gruytrode ${ }^{9}$. Czeski badacz zwrócił również uwagę, że z tekstem Zrcadlka koresponduje inny utwór poświęcony rzeczom ostatecznym: Zrcadlo věčného života, který se křst'an do něho vzhledné, spatři v něm čtyři budouci a posledni věci, totižto Smrt, Den Soudný, Muky Pekelni, Radost Nebeskou. Po raz pierwszy dzieło zostało wydrukowane w Pradze u Buryana Waldy w 1587 roku, a do końca XVIII wieku było wydawane jeszcze dziesięciokrotnie.

W 1606 roku ukazało się w Czechach anonimowe tłumaczenie jezuickiego traktatu o czterech rzeczach ostatecznych De quattuor novissimis vitae humanae, którego autorem był belgijski teolog Franciszek Coster, zatytułowane Čtyry poslední člověka věci: 1. Smrt. 2. Soud. 3. Peklo. 4. Ráj. S pobožným a užitečným jich uvážením sepsaný a vỉbec vydaný.

Z kolei w 1615 roku wyszło dzieło Havla Žalanskiego zwanego Phaëthonem: De quatuor hominum novissimis. To gest: $O$ čtyřech věcech kteréž se nejposlednějši jmenuji totiž, I. O Smrti, neb Smrtedlnosti naši. II. O Posledním Soudu. III. O Mukách Pekelních. IV. O Slávě Nebeské a životu věčném.

Autorzy traktatów każdej z czterech ostatecznych rzeczy poświęcają osobną część. Struktura poszczególnych partii wydaje się niemal identyczna — wszystkie zawierają krótki wstęp i podrozdziały dotyczące różnych aspektów rozważanej sprawy. Spośród rozpatrywanych tekstów stosunkowo najrozleglejszy jest

${ }^{6}$ Ibidem, s. 7.

7 Dzieło było wydane jeszcze dwukrotnie w latach 1600 oraz 1602 pod zmienionym tytułem: Cesta života. To jest: Tři spisy aneb Traktáty: I. Knižka Srdeční. II. Zrcadlo Téhodní. III. Pravidlo Šlechetného a Křest’anského života. Všechněm pobožným, tohoto převráceného věku, velice potřebni i užiteční.

${ }^{8}$ Por. J. Kowzan, Quattuor hominum novissima. Dzieje serii tematycznej czterech rzeczy ostatecznych w literaturze staropolskiej, Siedlce 2003, s. 51.

${ }^{9}$ Por. V. Dokoupil, Předlohy Konáčových Knížek srdečných: PhDr. Bohumíru Lifkovi k 85. narozeninám, „Listy Filologické” 1986, nr 3 (109), s. 178-179. Zob. także M. Kopecký, Literární dilo Mikuláše Konáče z Hodiškova, Praha 1962. 
traktat Žalanskiego. Autor rozszerza omawianą tematykę o treści, których nie ma w pozostałych dziełach, między innymi o opisanie tego, jakie powinny być pogrzeby, jak mają wyglądać groby, cmentarze czy w jaki sposób należy opłakiwać zmarłych.

Forma podawcza utworów o rzeczach ostatecznych w stosunku do traktatów ars moriendi nie zmienia się, zmianie ulega natomiast sytuacja odbioru nauki zawartej w tekstach — wyraźnie mówi się tu o wcześniejszym rozważeniu spraw czekających człowieka w przyszłości. Zdobyta wiedza ma posłużyć do takiego ułożenia dalszej drogi doczesnej, by jej koniec (bez względu na to, kiedy nastąpi) nie mógł nikogo zaskoczyćc ${ }^{10}$.

Jak zauważa Jacek Kowzan:

W medytacjach nad finałem egzystencji, ukierunkowanej na osiągnięcie stanu pokory, szczególne miejsce w tekstach poświęconych czterem rzeczom ostatecznym zajmuje kwestia omnipotencji śmierci. Jej wszechwładza rozciąga się nad wszystkimi ludźmi spolaryzowanymi ze względu na wiek, kondycję społeczną, wiedzę, profesję, posiadany majątek lub sprawowaną władzę, które nie chronią przed zgonem. Umierają książęta, żebracy, młodzi, starzy, biedni, bogaci. Taka enumeracja, służąca zaakcentowaniu egalitaryzmu wobec śmierci, jest swoistą inkarnacją toposu Mors omnis aequat ${ }^{11}$.

Wszyscy bez względu na stan społeczny muszą ulec potędze śmierci:

Nebot' ona žádnému neodpustí, ale takového práva užívá, že moří císaře i krále, nestydí se bohatého ani chudého, duchovního ani světského, papeže ani sedláka, žádnyt' se jí vyprositi ani vyplatiti nemuože, všemt' hroží, všeckny moří1 ${ }^{12}$.

W omawianych traktatach wykorzystywany jest także motyw ubi sunt qui ante nos fuerant ${ }^{13}{ }^{13}$ który modeluje wszechmoc śmierci, a jednocześnie wizję świata jako przestrzeni marności i destrukcji. Imiona wybitnych postaci służą za dowód, że każdego spotyka taki sam koniec:

Kde jsou knížata národův [...] kde jest Adam otec nás všech nejprvnější a nejdokonalejší [...]. Kde j[est] Salomoun nejmoudřejší: Kde jest Alexander nejmocnější: Kde j[est] Samson nejsilnější: Kde jest Kresus nejbohatější: Ti i všickni jiní mocní a slovutní v světě, jakožto poutníci a hosté, jako jednoho dne pominuli a všecky smrt srovnala ${ }^{14}$.

Idea vanitas łączy się z motywem grobu zrównującego wszystkich ludzi:

${ }^{10}$ Por. M. Włodarski, Ars moriendi w literaturze polskiej XV i XVI w., Kraków 1987, s. 194.

11 J. Kowzan, Quattuor hominum novissima..., s. 63.

12 Zrcadlo věčného života, který se křestan do něho vzhledné, spatři v něm čtyři budoucí a posledni věci, totižto Smrt, Den Soudný, Muky Pekelni, Radost Nebeskou, Staré Město Pražské $1607, \mathrm{k} . \mathrm{B} 2$.

${ }^{13} \mathrm{Na}$ temat toposu ubi sunt... zob. S. Skwarczyńska, Topos „,Ubi sunt qui ante nos fuerant?" oraz styczne z nim formacje treściowo-formalne w poezji europejskiego kręgu kulturowego, [w:] eadem, W orbicie literatury, teatru, kultury naukowej, Warszawa 1985, s. 80-150; D. Künstler-Langner, Idea vanitas, jej tradycje i toposy w poezji polskiego baroku, Toruń 1996, s. 147-161.

14 Zrcadlo..., k. B3-B3v. 
Leží tělo bezdušné, bez smyslu, mrzuté a na pohledění hrozné: Do zemi pohřbené, pomalu se smradem a červy rozleze, a po některém dni v popel se obratíc krom kostí nic nemá, které však jestliže shlídneš kdo a jaký by byl chudý neb bohatý, zeman neb sedlák, král neb ovčář nepoznáš ${ }^{15}$.

Degradacja ludzkiego ciała wyrażana za pomocą obrazów rozpadu zwłok, które stają się siedliskiem dla robaków, miała ujawniać znikomość życia. Środki perswazji typowe dla kultury późnego średniowiecza, lecz także charakterystyczne dla estetyki barokowej, aktywizowały wyobraźnię i oddziaływały na uczucia odbiorcy. Jak pisał Žalanský: „Nic zajisté není mrzčejšího a potupnějšího nad tělo v hrobě se rušící a hníjící"l6.

Nędzne i godne pogardy jest jednak nie tylko ciało człowieka, ale też wszelkie działania, wysiłki, urzędy godności, dystynkcje. Podlegają one przemijaniu, są nietrwałe, złudne, a nawet szkodliwe, ponieważ pociągają człowieka w fałszywym kierunku. Stała repetycja myśli o marności i złu świata ogniskuje się w zaleceniu ciągłej pamięci o śmierci, memento mori staje się sumą mądrości życiowej i przesłaniem ideowym traktatów ${ }^{17}$ :

Chceme-li tedy dobře duši své posloužiti, na věci budoucí pomněme, bud'to že ráno z lůže vstáváme, bud' že v večer spat jdeme, bud'to že chodíme, sedíme, jíme, pacujeme, vždycky každého času na smrt svou pamatujme, vždycky necht' nám v uších zní ten hlas Memento mori ${ }^{18}$.

Autorzy traktatów przekonują, że człowiek jest istotą piękną, lecz nietrwałą, znika i nie pozostawia po sobie śladu. Aby zobrazować tę tymczasowość i nietrwałość ludzkiej egzystencji, posługują się licznymi porównaniami zaczerpniętymi z różnych ksiąg Pisma świętego: życie przypomina więdnący kwiat, schnącą trawę, gasnący płomień, wsiąkającą wodę itp.

W omawianych dziełach występują obok siebie dwa określenia antonimiczne - pewność i niepewność:

Víme, že umřeme, ale nevíme kdy, nevíme kde, nevíme jakou smrtí. Nejistý jest čas, nejisté jest místo, nejistý způsob smrti. Smrti způsobové jsou rozliční: Tito smrtí přirozenou a pokojnou, jiní násilnou scházejí. Tito v ohni spáleni, jiní v vodách stopeni, jiní od zvěří sežráni bývají. Jedni opět doma, druzí na vojně neb přes pole umírají1 ${ }^{19}$.

${ }^{15}$ Čtyry poslední člověka věci: 1. Smrt. 2. Soud. 3. Peklo. 4. Ráj. S pobožným a užitečným jich uvážením sepsaný a vủbec vydaný práci ctihodného kněze Františka Kostera z Tovaryšstva jména Ježíšova, Olomouc 1606, s. 29.

${ }^{16}$ De quatuor hominum novissimis. To gest: O čtyřech věcech kteréž se nejposlednější jmenuji totiž, I. O Smrti, neb Smrtedlnosti naši. II. O Posledním Soudu. III. O Mukách Pekelních. IV. O Slávě Nebeské a životu věčném, spis v nově vydaný a složený od kněze Havla Žalanského, Nové Město Pražské 1615, ks. I, s. 20.

17 Podobnie w pieśniach z tego okresu, por. A. Nowicka-Jeżowa, Pieśni czasu śmierci..., s. 89106.

18 De quatuor..., s. 66.

19 Ibidem, s. 98-99. 
Śmierć może zaskoczyć człowieka w chwili, gdy nie będzie się tego spodziewał, co w traktacie Costera zostało porównane do złodzieja działającego pod osłoną nocy:

Jest pak onoho času okamžení, v kterém duše místa svého postoupiti má velmi nejisté. Pán Kristus smrt zloději přirovnává, který se tehdáž do domu neláme, když ví že hospodář bdí: než když se domnívá, žeby všickni zdřímavší, nic méně jako na zloděje nemyslilii ${ }^{20}$.

Lęk u każdego wywołuje więc z jednej strony niewiadomy czas nadejścia śmierci, z drugiej — nieświadomość losu po niej, nieznajomość miejsca wiecznego przeznaczenia. Nikt nie wie, ile czasu mu pozostało na ziemi ani w jakich okolicznościach przyjdzie mu umrzeć. Ponieważ śmierć definitywnie zamknie możliwość zmiany, czas dany za życia należy intensywnie wykorzystać do ustawicznej poprawy. Autorzy zachęcają do ekspiacji, nawołują do opamiętania się i nakłaniają do pełnienia dobrych uczynków. Pamięć śmierci niezbędna jest jako jasna wytyczna właściwej drogi, ale też jako jedyne słuszne remedium na nieprawości. Człowiek pokornieje, dzięki czemu zwalcza pierwszy i najważniejszy grzech - pychę; gardzi światem i czyni pokutę. Eschatologia wprzęgnięta zostaje w służbę moralizmu ${ }^{21}$. Jedynie stała gotowość do śmierci uwolni człowieka od niepewności losu po zgonie:

Uměti pak dobre umříti nic jiného není, než srdce spravené k Pánu Bohu, a dusi pozdvíženou každého času k Nebeským věcem míti: aby kdyžkoli smrt zavítala, duše jsouc hotová z těla vyjíti, příchod smrti žádostivě přivítala ${ }^{22}$.

Sąd Ostateczny przedstawiany jest w traktatach jako wydarzenie straszliwe i groźne: „O kterák veliké naříkání hř́šníkův bude, bázeň, strach, zubův skřípení, bolestí rozličné, zármutkové, ouzkosti takové, kteréž nebyli nikda ani od počátku světa"23. Odbywa się o blasku jutrzni, gwarantującym jawność procesu i skrupulatne zbadanie każdego uczynku i każdej myśli. W dziele Srdečné knižky następuje wyliczenie siedmiu oskarżycieli grzesznika przed Boskim Trybunałem (sumienie, Szatan, aniołowie, wszelkie stworzenia, ludzie skrzywdzeni przez człowieka, grzechy oraz niegodziwości, Chrystus).

We wszystkich traktatach sąd jest opisany jako dzień grozy, trwogi oraz ognia, służącego oczyszczeniu i oddzieleniu dobrych od złych, którzy zostali wezwani głosem trąby przed trybunał. Deskrypcja ta ma wywołać u czytelnika strach, przerażenie, skutkujące poprawą życia i porzuceniem drogi grzechu, ma

${ }^{20}$ Čtyry poslední..., s. 20-21.

21 Por. J. Kowzan, Quattuor hominum novissima..., s. 70.

22 Zrcadlo..., k. B2-B2v. Zob. również: Najvětši mudrost jest ustavičná pamět smrti. Když bude člověk vždycky s sebú nositi kudiž pojde na vieky hřešiti nebude, [w:] Mikuláš Konáč z Hodíškova, Srdečné knižky o čtyřech poslednich budúcích věcech, totiž o smrti, soudu, peklu a o radosti nebeské velmi přikladné. Též knižky, kteréž slovú Zrcadlko sedmi dnů hřišné duše, každému člověku potřebné a užitečné, Praha 1521, k. B.

${ }^{23}$ Zrcadlo..., k. B6v. 
uaktywnić człowieka, skłonić go do poszukiwania sposobów uniknięcia potencjalnego niebezpieczeństwa ${ }^{24}$.

W tłumaczeniu traktatu Costera zgodnie z dogmatyką katolicką występuje rozróżnienie sądu szczegółowego (partykularnego), na który stawiają się dusze zaraz po śmierci, czyli po rozłące z ciałem, oraz sądu ostatecznego (kolektywnego), odbywającego się w Dniu Pańskim:

Dvakrát pak jedenkaždý postaviti se musi před soudnou Stolici Krystovou: hned jak skona, a při obecním onom všeho světa soudu. Kterýžto obecní a veřejný soud, co se vejpovědí same dotýče, krom mzdy, která se tělu dá, nic s sebou nového nepřinese, než potvrzení bude toho všeho, co v osobním jednoho každého soudu nařízeno bylo ${ }^{25}$.

Dystynkcja ta była przeprowadzana $\mathrm{w}$ retoryce polemiki $\mathrm{z}$ odmienną koncepcją protestantów, dla których sąd tożsamy jest z paruzją. Žalanský jako wyraziciel kalwinizmu pouczał, że powtórne przyjście Chrystusa na ziemię będzie srogie, a rozstrzygnięcie definitywne. W dniu ostatecznym Pan wybudzi umarłych i będzie ich sądzić, wybranym da żywot wieczny i radość wiekuistą, natomiast bezbożnych skaże na piekło i wieczną karę: „vyvolení skrze vzkříšení $\mathrm{k}$ Břehu věčného blahoslavenství přistanou: ale bezbožní v Jezeře ohnivém a propasti pekelné na věky páleni budou" 26 .

W zależności od przynależności wyznaniowej różnie podchodzono także do kwestii czyśćca, którego rację bytu udowadniali katoliccy autorzy, a protestanccy odrzucali.

Idea trzeciego miejsca życia pozagrobowego zaczęła się formować już w drugiej połowie XII wieku, dopiero jednak na soborze florenckim (1439-1443) i soborze trydenckim (1563) Kościół prawdy te ujął w dogmaty wiary. Przyjęty wówczas katechizm mówił, że ogień czyśćcowy oczyszcza dusze pobożnych, poddane chwilowej karze, tak by mogły wejść do krainy wieczności. Dusze zatrzymane w tym miejscu są wspomagane modlitwą wiernych, a przede wszystkim ofiarą ołtarza $^{27}$.

Coster o tych, którzy trafiają do czyśćca, pisał:

Jsou tedy třetí mezi těmi prostřední, a ti katoličtí přátelé Boží a milostí Boží ozdobeni, kteří dle vnitřního Ducha svatého daru a přátelství Božího před pekelním ohněm jistí a bezpeční jsou, a však dle některých poskvrn a ostatkům hříchův, nejsou tak čistotní, aby hodni byli zdílnosti a domácnosti Svatých ${ }^{28}$.

Zwolennicy reformacji ostro zarzucali swym adwersarzom wiarę w czyściec, twierdząc, że pomiędzy niebem a piekłem nie istnieje pośrednictwo i dlate-

24 Por. J. Kowzan, Quattuor hominum novissima..., s. 195.

${ }^{25}$ Ctyry poslední..., s. 45.

${ }^{26}$ De quatuor..., ks. IV, s. 107.

${ }^{27}$ Por. J. Le Goff, Narodziny czyśćca, przeł. K. Kocjan, Warszawa 1997; A. K. Turner, Historia piekła, przeł. J. Jarniewicz, Gdańsk 1996, s. 106-110; G. Minois, Historia piekła, przeł. A. Kędzierzawska, B. Szczepańska, Warszawa 1998, s. 116-120.

28 Čtyry poslední..., s. 86. 
go żaden „stan tymczasowy” nie ma racji bytu. Teoriom zakładającym istnienie czyśćca kategorycznie sprzeciwia się Žalanský, twierdząc, że jest to: „smyšlenka pohanská, poetická, básnivá z Platona a Virgilia vzatá a od nich toliko pro zisk přijatá a uvedená" 29 . Autor podpiera się argumentem, że zaświatów pośrednich nie było w Piśmie świętym: „Ale my z milosti boží to víme a známe, že Písma svatá dva toliko prŕbytky ukazují, do nichž se duše mrtvých shromaždují jeden spasení a blahoslavenství, druhý zatracení"30. Žalanský wykorzystuje tę okazję również, by zaatakować oponentów religijnych i skrytykować praktykę odpustów za dusze czyśćcowe: „Našet’ tedy věc jej, abychom jich s tím tupým a marným ohněm očistce jejich zanechali a nic se ho nebáli. Nic zajisté on jiného nevyčištuje, než truhly, statky a měšce těch, kteř́ se ho boji’”31.

W utworze Knižky srdečné nie ma zróżnicowania sądu szczegółowego i powszechnego, nie występują w nim też rozważania na temat czyśćca. Wspomniany został jedynie ogień trzeciego miejsca. Należy to tłumaczyć czasem powstania dzieła Cordiale quattuor novissimorum, które stanowiło pierwowzór dla czeskiego przekładu. Jak zostało wspomniane, najstarsze manuskrypty łacińskiego traktatu pochodzą z końca XIV wieku, a więc powstawał on w okresie poprzedzającym wprowadzenie przez Kościół dogmatu o istnieniu czyśćca ${ }^{32}$.

Piekło w traktatach o czterech rzeczach ostatecznych odznaczało się konkretnością i wyrazistością, przez co miało napawać lękiem. Perswazja nastawiona była na opamiętanie się grzeszników. Straszenie miało charakter dyscyplinujący, ponadto pozwalało Kościołowi utrzymywać kontrolę nad wierzącymi. Obraz piekła urozmaicały opisy tortur, ognia piekielnego, odoru i ciemności. Skazańcy cierpieli męki zmysłowe, którymi wcześniej grzeszyli i znieważali boskie przykazania. Katalog przewinień tworzyły wszystkie ciężkie grzechy śmiertelne. Opierając się na Piśmie świętym, przedstawiano piekło jako karę wieczną (Mt 5, 22), miejsce, „gdzie robak nie umiera, a ogień nie gaśnie” (Mk 9, 43) i gdzie „będzie płacz i zgrzytanie zębów” (Mt 8, 12). Autorzy traktatów przekonywali, że żaru ziemskiego nie sposób porównywać z ogniem piekielnym: , a mnoho řek1 i nějaký Aegidius Romanus, že oheň tento náš přirozený proti ohni pekelnýmu jest jako oheň malovaný" ${ }^{\prime 3}$. Płomień w piekle jest wieczny i nieugaszony, a jego natężenie nie słabnie. Ogień ma właściwości destrukcyjne - ciała i dusze poddane obróbce cieplnej są dotkliwie parzone, co nie zmienia jednak ich postaci: „Zatracenci budou plní rozličných bíd a nevymluvných bolestí. Budou za pokrm ohni a však nikda sežráni ani spáleni nebudou. Jazyky své kousati budou, nebo jako psy hlad trpěti budou a Pánu Bohu se rouhati budou"34. Bólu piekielnego

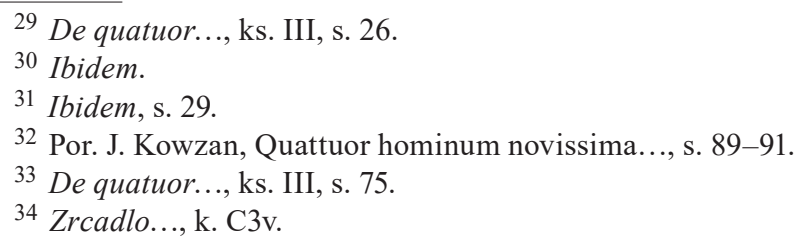


nie wyrazi żaden język, a piekielnych jęków z powodu smutku i braku nadziei na jakikolwiek ratunek nie zniesie żadne ucho.

Podstawową karą dla nieszczęśników w piekle jest niemożność widzenia Boga. Repertuar cierpień uzupełniają uczucia żałości, wstydu i wyrzuty sumienia. Potępieńcy są głodzeni, a jedyne pożywienie to siarka i ogień. Ponadto w piekle panuje ciasnota i wieczny mrok: „nebot' bezbožní na věčnost světla neužijí, světla tělesného i duchovního budou zbaveni" ${ }^{35}$, a przeraźliwą perspektywą infernalnych tortur jest nieskończoność ich trwania.

Wizje nieba zawarte $w$ traktatach o czterech rzeczach ostatecznych w zestawieniu z opisami piekła nie tylko są krótsze, lecz także wydają się mniej twórcze, bardziej schematyczne, statyczne i abstrakcyjne. Z jednej strony swobodę autorów ograniczały utrwalone biblijne opisy raju, z drugiej - jako pozytywna motywacja miały jedynie wabić i przyciągać, nie potrzebowały barwnych szczegółów ${ }^{36}$.

Niebo jest przedstawiane jako królestwo piękna, wspaniałe miasto sprawiedliwych z bramami wykonanymi z szafiru, szmaragdu, innych drogocennych kamieni i pereł. Panuje tam wieczna jasność, której źródło stanowi sam Bóg: „Nebo tam noci nikda nebude, aniž potřebovati budou slunce: Nebo Pán Bůh sám bude světlo jejich"37. Rozbrzmiewająca niebiańska muzyka powoduje, że nasycenie radością i czystą, doskonałą miłością jest pełne. Nie ma w niebie żadnych nieprzyjemnych rzeczy znanych z ziemskiego bytowania, takich jak głód, pragnienie, choroby czy starość. To miejsce wszelkiej obfitości, wolne od smutku, boleści i bojaźni, czyli elementów wypełniających otchłań piekielną. Autorzy podkreślają, że rozkosz będąca udziałem zbawionych jest niewysłowiona:

[...] co by byl život ten věčný a blahoslavený, to se poněkud ukázati může, místně pak právě a zcela se vyložiti, ani jazykem vymluviti, ani perem vypsati, ani rozumem stihnouti, ani serdcem vyrozuměti nemůže $[\ldots]^{38}$; Nebo tam jest pokoj věčný a odpočinutí bezpečné, život dokonalý, radost věčná. Nebo odplata svatých tak jest veliká, tak hojná, tak mnohá, a tak drahá, že ji žádný lidský jazyk nikoli vypraviti nemuože [...] $]^{39}$.

Warto zwrócić uwagę, że Žalanský w swoim traktacie odnosi się do zasady protestantyzmu sola gratia, głosząc, że zbawienie jest jedynie wyrazem łaski Bożej, „niezasłużonym darem”, a nie nagrodą za jakiekolwiek zasługi grzesznika:

[...] nejsa hnut a veden naší ňákou spravedlností (která při nás žádná není), ale svou dobrotivostí a láskou slávy své v plnění slibů svých. Varujme se tedy, abychom zásluhami našimi nepejchali a jim se nedůvěřovali, jako bychom sami z sebe života věčného hodni byli. Ale

\footnotetext{
35 De quatuor..., ks. III, s. 108.

36 J. Mikulec, Náboženskýživot a barokní zbožnost v českých zemích, Praha 2013, s. 226.

${ }^{37}$ Zrcadlo..., k. C7v.

${ }^{38}$ De quatuor..., ks. IV, s. 40.

39 Zrcadlo..., k. C8-C8v.
} 
učme se znáti a slaviti pravdu a dobrotu Boží, kterýž nám nehodnýmpro slíby své dobře činiti ráčí. Žádný člověk skrze skutky a zásluhy své spasen a ospravedlněn nebyl ${ }^{40}$.

Podsumowując, należy stwierdzić, że autorzy wszystkich traktatów podejmujących temat czterech ostatecznych rzeczy człowieka nakłaniają czytelników do określonej postawy życiowej: czynienia pokuty, wzgardzenia światem doczesnym i przygotowania się do wieczności. Wykorzystują w tym celu retoryczne środki perswazji typowe dla literatury dydaktycznej, mającej przestrzegać, zachęcać, napominać. Celem ostatecznym człowieka jest życie wieczne w Królestwie Niebieskim, które w prezentowanych utworach osiąga standard dobra absolutnego. Zdobyta wiedza ma pomóc w takim ułożeniu dalszej drogi życiowej, by jej kres, niezależnie od tego, kiedy nastąpi, nie mógł nikogo zaskoczyć. Problematyka eschatologiczna oraz jej implikacje, takie jak odpusty, modlitwy, msze za dusze zmarłych, stanowiły obszar sporu w czasie gwałtownych polemik religijnych między protestantami a katolikami. Właśnie dlatego autorzy prezentują w dziełach stanowisko zgodne z konfesją, której są wyznawcami.

Podjęty temat daje szerokie pole do interpretacji, dlatego też niniejsze rozważania należy uznać za przyczynek i zachętę do dalszych badań nad traktatami o czterech rzeczach ostatecznych.

\section{Bibliografia}

Čtyry poslední člověka věci: 1. Smrt. 2. Soud. 3. Peklo. 4. Ráj. S pobožným a užitečným jich uvážením sepsaný a vỉbec vydaný práci ctihodného kněze Františka Kostera z Tovaryšstva jména Ježíšova, Olomouc 1606.

De quatuor hominum novissimis. To gest: O čtyřech věcech kteréž se nejposlednějši jmenuji totiž, I. O Smrti, neb Smrtedlnosti naši. II. O Posledním Soudu. III. O Mukách Pekelních. IV. O Slávě Nebeské a životu věčném, spis v nově vydaný a složený od kněze Havla Žalanského, Nové Město Pražské 1615.

Dokoupil V., Předlohy Konáčových Knižek srdečných: PhDr. Bohumíru Lifkovi k 85. narozeninám, „Listy Filologické” 1986, nr 3 (109).

Kopecký M., Literární dílo Mikuláše Konáče z Hodiškova, Praha 1962.

Kowzan J., Quattuor hominum novissima. Dzieje serii tematycznej czterech rzeczy ostatecznych w literaturze staropolskiej, Siedlce 2003.

Král P., ,Knižka o smrti” Mikuláše Krupěhorského připrava ke smrti v českém prostředi na přelomu 16. a 17. století, [w:] K výzkumu zámeckých, měštanských a cirkevnich knihoven, „Vita Morsque et Librorum Historia (Opera Romanica)" 2006, nr 9.

Král P., Knihy o dobrém umírání v českém prostředi ve druhé polovině 16. a první půli 17. století, [w:] Cirkev a smrt. Institucionalizace smrti v ranem novověku, red. M. Holý, J. Mikulec, Praha 2007.

Künstler-Langner D., Idea vanitas, jej tradycje i toposy w poezji polskiego baroku, Torun 1996.

Le Goff J., Narodziny czyśćca, przeł. K. Kocjan, Warszawa 1997.

Mikuláš Konáč z Hodíškova, Srdečné knižky o čtyřech posledních budúcich věcech, totiž o smrti, soudu, peklu a o radosti nebeské velmi př́kladné. Též knižky, kteréž slovú Zrcadlko sedmi dnů hřišné duše, každému člověku potřebné a užitečné, Praha 1521.

${ }^{40}$ De quatuor..., ks. IV, s. 131. 
Mikulec J., Náboženský život a barokní zbožnost v českých zemích, Praha 2013.

Minois G., Historia piekła, przeł. A. Kędzierzawska, B. Szczepańska, Warszawa 1998.

Nowicka-Jeżowa A., Pieśni czasu śmierci. Studium z historii duchowości XVI-XVII wieku, Lublin 1992.

Skwarczyńska S., Topos „Ubi sunt qui ante nos fuerant?” oraz styczne z nim formacje treściowo-formalne w poezji europejskiego kręgu kulturowego, [w:] eadem, W orbicie literatury, teatru, kultury naukowej, Warszawa 1985.

Sokolski J., Wprowadzenie do lektury, [w:] K. Bolesławiusz, Przeraźliwe echo trąby ostatecznej, Warszawa 2004.

Turner A. K., Historia piekta, przeł. J. Jarniewicz, Gdańsk 1996.

Vašica J., Písně o čtyřech posledních věcech člověka, Praha 1944.

Włodarski M., Ars moriendi w literaturze polskiej XV i XVI w., Kraków 1987.

Zrcadlo věčného života, který se křestäan do něho vzhledné, spatři v něm čtyři budouci a poslední věci, totižto Smrt, Den Soudný, Muky Pekelní, Radost Nebeskou, Staré Město Pražské 1607.

\section{Treatises on four ultimate truths about the human condition in 16th and 17th century Czech literature (an outline of issues)}

\section{Summary}

Czech literature of the 16th and 17th century was for readers of that time an important source of admonishment concerning death and afterlife. Manuals about the art of dying - ars moriendi books - provided ample advice on how to die a "good death". Besides that, their authors focused also on other issues of ultimate importance for human beings, i.e. death, God's judgment, heaven and hell. The aim of the treatises was to make readers lead a good life through constant pondering over death and the uncertainty of the soul's fate in the afterlife. Descriptions of various tortures suffered by the damned in hell were meant to frighten sinners, make them repent and change their lives. Descriptions of heaven, on the other hand, were supposed to lure people into doing good. According to the Catholic dogma, after death, the soul can go to heaven, hell or purgatory. The Protestant Reformation rejected purgatory as wishful human fiction, and returned to a traditional dualistic view of the afterlife.

Keywords: death, the Last Judgment, purgatory, hell, heaven

\section{Traktáty o čtyřech posledních věcech člověka v české literatuře 16. a 17. století (náčrt problematiky)}

Obsah

Česká náboženská vzdělávací literatura 16. a 17. století představovala pro čtenáře důležitý zdroj poučení o smrti a posmrtném životě. Příručky štastného umírání — knihy ars moriendi přinášely rady, jak má dobrá smrt vypadat. Kromě této problematiky se autoři zabývali tématy souvisejícími s posledními věcmi člověka, to je smrtí, božím soudem, peklem a nebem. Cílem traktátů bylo přimět čtenaře k dobrému životu prostřednictvím myšlenky na smrt a nejistý posmrtný osud 
duše. Líčení pekelných trestů mělo vyvolat u hř́šníků hrůzu, přimět je, aby změnili své chování a nastoupili cestu pokání. Popisy ráje měly lákat a přitahovat. Podle katolíků duše po smrti mohla jít do nebe, pekla nebo ji čekal očistěc, kde měla smýt hříchy a poté vstoupit na nebesa. Reformace odmítla učení o očistci, a proto na něm protestanští autoři zdůrazňovali lidský výmysl.

Kličová slova: smrt, poslední soud, očistěc, peklo, nebe 